CENTRE POUR LA RECHERCHE ECONOMIQUE ET SES APPLICATIONS

Document de travail (Docweb) $\mathrm{n}^{0} 1510$

\title{
The Spanish Productivity Puzzle in the Great Recession
}

Laura Hospido

Eva Moreno-Galbis 


\title{
The Spanish Productivity Puzzle in the Great Recession ${ }^{1}$
}

Laura Hospido ${ }^{2}$ and Eva Moreno-Galbis ${ }^{3}$

\begin{abstract}
While Spain has traditionally underperformed its European neighbors in terms of labor productivity, this trend reverses after 2007. Part of the explanation for this reversal is likely to be the direct impact of decreasing labor inputs relative to capital. Using a longitudinal sample of Spanish manufacturing and services companies between 1995 and 2012, we show that the recent increase in Spanish aggregate productivity is also driven by the behavior of firm-level total factor productivity (TFP), and by composition effects. By combining firm-level information on balance sheet items, collective agreements and imports/exports, we document that firm TFP is positively correlated to firm-specific collective agreements and access to external markets during the whole period. In addition, our estimates indicate that firm TFP was negatively correlated to the proportion of temporary workers during the expansionary period (1995-2007), but positively correlated during the crisis (2008-2012).
\end{abstract}

Keywords: Labor productivity, TFP, temporary workers, collective agreements, exporting firms. JEL Classification: J24, J21, J52.

\section{L'énigme de la productivité espagnole durant la grande récession}

Résumé : Alors que la productivité du travail en Espagne a traditionnellement été inférieure à celle de ses voisins européens, cette tendance se renverse après 2007. Une partie de ce retournement peut être expliquée par la diminution de la quantité de facteur travail utilisé par rapport au capital. En nous servant d'un panel de données des secteurs manufacturier et des services non financiers pour la période 1995-2012, nous montrons que l'accroissement récent de la productivité du travail au niveau agrégé s'explique également par le comportement de la productivité totale des facteurs (PTF) au niveau des firmes ainsi que par des effets composition. En combinant des informations contenues dans le bilan des entreprises, dans les accords collectifs et sur les importations/exportations, nous estimons une corrélation positive entre la PTF de la firme pendant la période considérée et deux marges d'ajustement : l'utilisation du marché extérieur et l'engagement de la firme dans un accord collectif au niveau de l'entreprise. En outre, la PTF de la firme a été négativement corrélée à la proportion de travailleurs temporaires durant la période d'expansion (1995-2007) mais positivement pendant la crise (2008-2012).

Mots-clefs : Productivité du travail, PTF, travail interimaire, conventions collectives, entreprises exportatrices.

Classification JEL : J24, J21, J52.

1 This text is a background paper of a more general research, part of the CEPREMAP project "Productivity", which also covers Germany, France and UK. The authors specially thank our colleagues on the productivity project, seminar participants at the DARES-CEPREMAP conference 2014 on American and European Labour Markets and the CEPREMAP conference 2015 on Productivity puzzles in Europe, and in particular Tito Boeri, Alex Bryson and Gilles Saint Paul for stimulating discussions. We also thank an anonymous referee, Eric Bartelsman, James Costain, Cristina Fernàndez, Luis Diez-Catalan, Juan Francisco Jimeno, Aitor Lacuesta, David Lopez, José Manuel Montero, Enrique Moral-Benito, Roberto Ramos, Antonio Rodriguez-Caloca, Valerie Smeets and Ernesto Villanueva for useful comments, as well as seminar participants at BBVA Research and those of the ESEM 2014, ESPE 2014, JEI 2014, PET 2014, and SAEe 2014 meetings. All remaining errors are our own. Eva Moreno-Galbis acknowledges the financial support of the CEPREMAP project "Productivity". The opinions and analysis are the responsibility of the authors and, therefore, do not necessarily coincide with those of the Banco de España or the Eurosystem

2 Banco de España and IZA.

3 GRANEM, CREST, GAINS-TEPP, Cepremap and IRES. 


\section{Introduction}

The divergent productivity growth experiences of the United States and various countries in Europe during the current economic crisis highlight the importance of understanding the factors underlying labor productivity growth (see Figure 1). In particular, the slowdown of Spanish labor productivity growth between the mid-1990s and 2000s contrasts with the positive productivity growth in the US and other European countries. ${ }^{1}$ Since 2007, the differential has mostly gone in the opposite direction. Determining the temporary or permanent nature of the factors underlying recent productivity growth is important for predicting Spanish future competitiveness.

Figure 1: Labor productivity growth in Spain, US, France, Germany, and UK (\%).

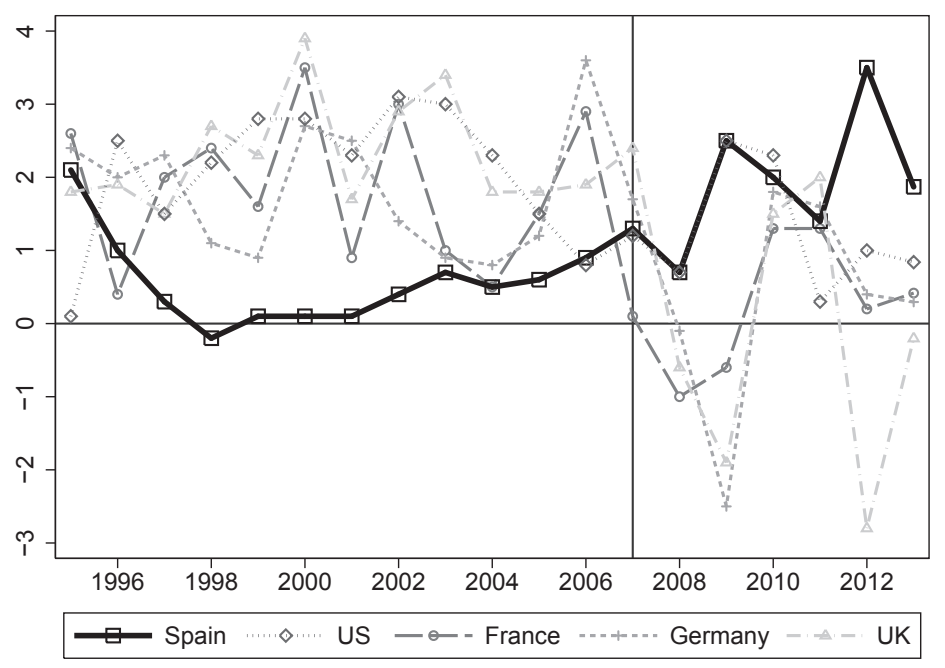

Notes: Source OECD. Labor productivity defined as GDP per hour worked.

From an accounting point of view, GDP per capita, $Y / P$, can be decomposed into labor productivity, $Y / L$, and employment, $L / P$, where $Y$ is GDP, $P$ population, and $L$ labor (measured as number of workers or hours of work). In Spain, the divergent evolution of GDP per capita and of labor productivity during the recent crisis is clearly related to the very adverse conditions in the labor market (see figure 2). Since 2007, unemployment has increased (particularly for men due to the downsizing of the construction sector) reaching $25 \%$ of the active population in 2012, and 40\% for people between 16 and 29 years old. This evolution of the unemployment rate is mainly due to the massive destruction of jobs rather than the arrival of new entrants into the labor market. Moreover, job destruction has disproportionately affected employees with temporary contracts, which are usually associated with low productivity positions (see figure 3). Thus, the recent improvement in aggregate labor productivity could be related to a sharp drop in employment while the other factors of production remain fairly constant, but it could also be a composition effect due to the massive destruction of less productive positions.

\footnotetext{
${ }^{1}$ See, for instance, Dolado et al. (2011).
} 
Figure 2: GDP per capita, labor productivity and employment over total population in Spain (rates of growth, \%).

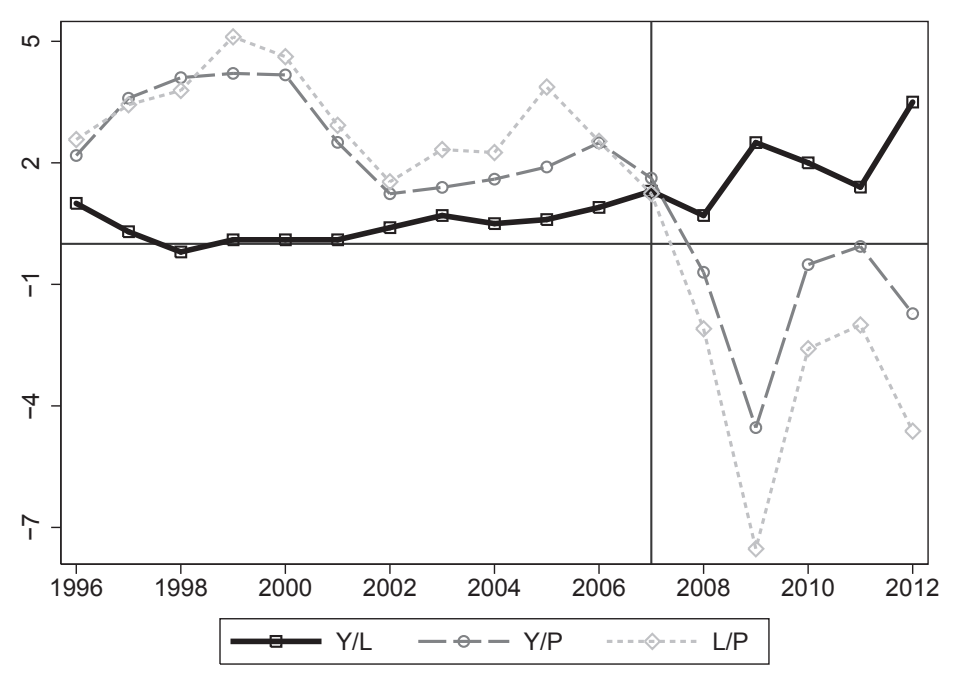

Notes: Source OECD.

Figure 3: Share of temporary contracts in Spain (\%).

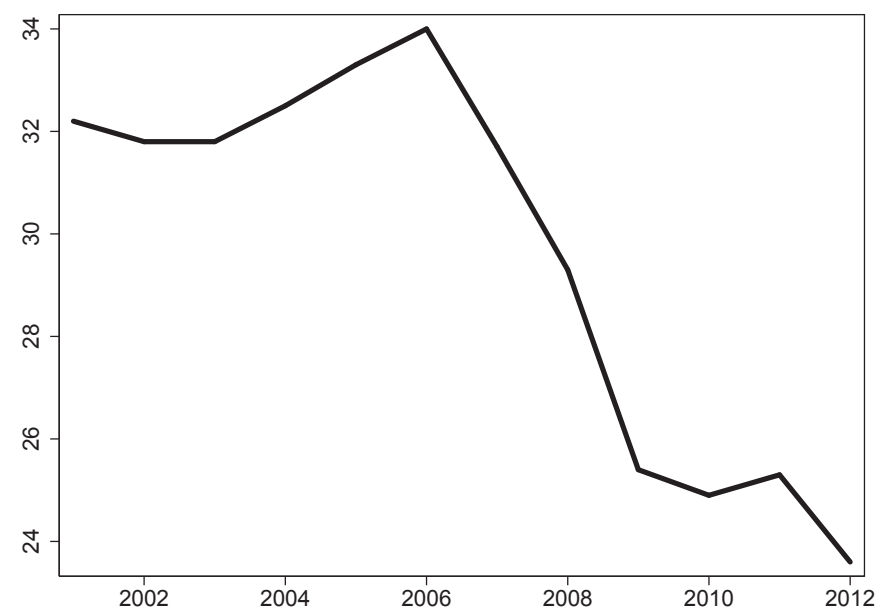

Notes: Source Spanish National Statistical Institute. 
Under the assumption of a standard Cobb-Douglas production function, $Y=A K^{\alpha} L^{1-\alpha}$, labor productivity equals

$$
\frac{Y}{L}=A \cdot\left(\frac{K}{L}\right)^{\alpha}
$$

where $A$ is the total factor productivity (TFP) traditionally associated with technological progress, $K$ is capital, and the ratio $K / L$ is known as capital deepening. Denoting labor productivity as $y=Y / L$, and capital deepening as $k=K / L$, we can rewrite equation (1) in growth terms as:

$$
\dot{y}=\dot{A}+\alpha \dot{k}
$$

In the neoclassical framework, capital stock is an endogenous variable that depends on TFP growth. In a long run steady state (a situation where all per capita variables are growing at a constant rate) one can show that the growth of capital intensity is the same as the rate of growth of labor productivity, so that, $\dot{y}=\frac{\dot{A}}{1-\alpha}$. Hence, in the long run, TFP growth would be the most informative predictor of future trends in productivity. ${ }^{2}$

Under this conceptual framework, the contribution of the paper is twofold. First, our study estimates the evolution of TFP at both the macro and the micro levels in Spain during the period 1995-2012. We seek to determine whether the evolution of aggregate productivity results from a change in the TFP level of the majority of firms or if instead reflects composition effects. Second, we study the relationship between the evolution of TFP at the firm level and available margins of adjustment, such as the mix of labor contracts used by the firm, the type of collective agreement, and the possibility of exporting or importing from abroad. In particular, we focus on the importance of these flexibility margins during the recent economic crisis (2008-2012).

We find that the evolution of aggregate productivity in Spain during the Great Recession largely responds to the adverse conditions in the labor market, but also to the evolution of TFP and composition effects. In addition, by combining the information at the firm level on balance sheet items, collective agreements and imports-exports, we are able to establish that commitment to a collective agreement at the firm level and access to external markets are positively related to TFP performance during the whole period. Moreover, we estimate that firm TFP was negatively correlated with the share of temporary workers during the expansion period, but positively correlated during the crisis. We interpret this sign reversal as the result of a changing composition of temporary workers in the labor market.

The rest of the paper is organized as follows. Section 2 incorporates a review of related literature. Section 3 describes the different data sources as well as the construction of our final sample. In Section 4 we explain our methodological approach. Section 5 documents the evolution of the Spanish TFP, both at the micro and macro levels, whereas in Section 6 we discuss the role of the flexibility margins in that evolution. Finally, Section 7 concludes.

\footnotetext{
${ }^{2}$ See Sargent and Rodriguez (2001) for a further discussion.
} 


\section{$2 \quad$ Related Literature}

The interest concerning the evolution of Spanish productivity is not new. However, to our knowledge, none of the previous works considers the recent crisis period after 2007. The paper dealing with the closest period to ours is Mora-Sanguinetti and Fuentes (2012), who use data for 1996-2007. They claim that the relatively weak performance of Spain largely reflects the low growth of the TFP within a wide range of sectors (with a limited impact of composition effects), while capital stock and educational attainment of the workforce have grown relatively strongly. They argue that Spain needs more flexible labor market, business environment and collective bargaining system, to improve productivity. They conclude that the acceleration of productivity in the mid-2006 was due to cyclical and temporary factors.

The role of institutions as a major determinant of productivity and efficiency of the Spanish economy is also analyzed in Alonso-Borrego (2010), Boldrin et al. (2010) and Gonzalez and MilesTouya (2012). Using the Balance Sheets of the Bank of Spain for the period 1983-2006, AlonsoBorrego (2010) reaches three major conclusions. First, the under-development in the service sector towards more competition may be preventing firms to increase their levels of specialization while outsourcing non-manufacturing activities. Second, increases in industry competition boost firms to improve their performance, especially in the case of service firms. Finally, the share of temporary employment tends to reduce productivity (while increasing employment), specially in the service sector. ${ }^{3}$

Boldrin et al. (2010) analyze the growth of the Spanish economy since the advent of democracy until today. They conclude that over the past 30 years Spain has experienced two long growth cycles. Between 1978 and 1993 the economy was characterized by a small increase in employment and a considerable rise in productivity, while between 1994 and 2008 there was a spectacular increase in employment and a small gain in productivity. The authors show that the characteristics of the labor market in Spain, with a dual system that protects permanent workers at the expense of temporary ones and an inefficient collective wage bargaining system, have played a very relevant role in explaining the observed growth pattern of Spain.

In a more recent work, Gonzalez and Miles-Touya (2012) analyze the impact of the labor market reforms in 1994 - restricting the use of temporary contracts - and in 1997 - reducing the severance payments of permanent contracts - on the efficient allocation of permanent labor. They find that these reforms did affect the allocative efficiency of the permanent labor input. They interpret these results as implying that the expected labor adjustment costs increased when the severe restrictions on using temporary workers were not accompanied by a sufficient reduction in the severance payments due to permanent workers.

Pilat (2005) estimates that, for the second half of the 1990s, low levels of labor productivity account for two-thirds of the gap in income levels between Spain and the United States. He argues that, to improve productivity growth, Spain should reduce the gap in employment protection

\footnotetext{
${ }^{3}$ This latter result is consistent with Aguirragabiria and Alonso-Borrego (2009) and Dolado et al. (2011).
} 
legislation between permanent and temporary workers, reinforce capital deepening and increase the level of human capital. He attributes the weak performance of TFP to the small contribution to productivity of the Information and Communication technologies (ICT) producing sector, the weak growth of TFP in ICT-using services, the relatively low investment in Research and Development $(\mathrm{R} \& \mathrm{D})$, the strong regulations in the retailing sector, the relatively high administrative burdens on start-up firms, the strict employment legislation and the not favorable environment for entrepreneurship.

The importance of $R \& D$ expenditures in determining the differences in productivity across firms and the evolution of firm-level productivity over time is also analyzed in Doraszelski and Jaumandreu (2013) using an unbalanced panel of more than 1800 Spanish manufacturing firms in nine industries during the 1990s. They also show that the link between R\&D and productivity is subject to a high degree of uncertainty, non-linearity and heterogeneity.

Mas and Quesada (2006) point towards the construction sector, the wholesale, retail trade and repairs sector and hotels and catering sector, as the main responsible of the poor performance of Spanish productivity over the period 1995-2004. If their negative contribution is eliminated, labor productivity would have presented a positive rate of growth of $0.67 \%$, instead of the actual negative rate of $-0.29 \%$. They underline the incapacity of Spain to extract all the benefit from large improvements in worker's training and educational levels. From their point of view, the negative contribution of TFP to economic growth in Spain is due to the small presence of ICT producing sectors, the relative small share of ICT-investment on total investment, the low penetration of ICT-assets, the higher cost of ICT, the low use of ICT at schools and the very poor technical formation and training.

Martinez et al. (2008) remark that the negative pattern of Spanish productivity since the midnineties (due to the bad behavior of TFP), occurred actually in a context where investment in ICT assets was increasing at high rates. They refer to this phenomenon as the Spanish Productivity Paradox. They argue that benefits of ICT need time to materialize. Adjustment costs and inefficiencies derived from inappropriate qualifications in the labor force lead to a transitional dynamics in which productivity suffers low and even negative growth rates. New organizational forms at the plant level and human capital accumulation adapted to the new equipment have to be carried out. Competitive factors, services and goods' markets also appear as a necessary condition for the optimal development of ICT because this environment minimizes adjustment costs.

Finally, although out of the scope of this paper, there also exists a wide literature analyzing the relationship between productivity growth and firm dynamics in Spain. Using data for the manufacturing sector in the 1990s, Fariñas and Ruano (2004) conclude that established firms are the main contributor to productivity growth; whereas Huergo and Jaumandreu (2004) conclude that, for some years, new firms display higher productivity growth than average. Jimeno and Sanchez-Mangas (2006) quantify that established firms account for 90\% of total productivity growth. Lopez-Garcia et al. (2007) extend the analysis to the service sector in the period 
1996-2003, and they conclude that the main engine of productivity growth in most sectors is the productivity improvement of established firms (particularly of large firms). Moreover, firms entering or exiting display a negative contribution (lower for large firms).

\section{The Data}

Our data set combines information from several data sources. Data on the annual accounts of firms and on the number of employees by type of contract, capital, and intermediate inputs were obtained from the Banco de España's Central Balance Sheet Data Office (CBSO) and from the Mercantile Registries. Information on the type of collective agreements comes from the Collective Agreement Registries. Finally, information on imports and exports is provided by the Balance of Payment Registries. We explain in detail the content of these databases and the merging procedure below.

\subsection{Data Sources and Definition of Main Variables}

Since 1991, under the cooperation agreements signed with the Ministry of Justice and the Spanish Association of Property and Mercantile Registrars, the Banco de España's CBSO and the Mercantile Registries have been working together to facilitate the statistical use of the annual accounting reports that companies are legally required to fill with the mercantile registry of the province in which their registered office is located. ${ }^{4}$ This cooperation allows us to have an unbalanced panel of firms in manufacturing and non-financial services industries from 1995 to 2012 .

The information available for each firm in each year includes: business name, location (5-digit postal code), several balance sheet items, profit and loss account items, standard financial ratios, and sector of activity at the 4-digit level. ${ }^{5}$ Employment is measured as the number of employees, disaggregated by contract type in permanent (those with an indefinite or permanent contract) and temporary employees (those with a fixed-term or temporary contract). ${ }^{6}$

Gross output at retail prices is calculated as total sales, plus the change in finished product

\footnotetext{
${ }^{4}$ All firms in Spain are required by law to deposit their annual accounts at the Mercantile Registries. However, a large number of small firms do not fulfill the reporting requirement because it is costly for them and the associated fines are small. The main advantage of complying is that submitting the annual accounts is a usual requirement to obtain loans from commercial banks and government contracts. Almunia and López-Rodríguez (2012) compare the size of the data set from the Mercantile Registries to the number of firms submitting corporate income tax returns to the tax agency, and they find that it contains information from approximately $85 \%$ of firms with annual revenue between $€ 1.5$ - $€ 60$ million that submitted a corporate tax return to the Spanish tax agency. The percentage is close to $90 \%$ for firms larger than $€ 60$ million, but just below $50 \%$ for firms smaller than $€ 1.5$ million.

${ }^{5}$ In practice, we consider 10 different sectors: Agriculture, Extractive, Manufacture, Energy, Construction, Sales, Transport, Tourism, Education-Health, Other non-financial services.

${ }^{6}$ To maintain measurement consistency, the number of temporary employees is calculated in annual terms by multiplying the number of temporary employees along the year times the average number of weeks worked by temporary employees and divided by 52 .
} 
inventories and other income from the production process, minus taxes derived on the production (net of subsidies). Output is deflated with the corresponding year and economic activity (2 digit national activity classification) value added deflator.

Intermediate inputs at retail prices are directly reported by firms in the CBSO. For those firms from the Mercantile Registries, intermediate inputs are obtained as the addition of provision supplies and operating expenses. Intermediate inputs are deflated by the intermediate input price index of the year and economic activity (2 digit national activity classification).

Value added is computed as the difference between gross output and intermediate inputs. Productivity results from the ratio between value added and the number of employees.

Capital includes both physical and intangible capital. It is recorded at book value and deflated using the price index of investment in equipment goods by year and economic activity ( 2 digit national activity classification).

We also use as control variables additional information at the firm level, such as sector of activity, size, age, location, or standard financial ratios. Particularly, we consider two financial ratios revealing the firm's debt structure. The first one, is referred as the debt ratio and is defined as the ratio between the firms' debt (long run and short run debts) over the firm's own financing (or equity financing). This debt ratio aims to measure the intensity of the debt compared to the firm's own funding and it reveals the degree of influence of third parties in the functioning and financial balance standing of the company. The second ratio is referred as the short term debt ratio and is defined as the share of short run debts over total liabilities (total debts). ${ }^{7}$

Information on collective agreements is obtained from the Collective Agreement Registries. In Spain, there exist five levels of collective agreement negotiation: at the firm level, at the municipality level, at the province level (geographical unit below the region), at the regional level and at the national level. The level of the collective agreement to which the firm is committed may have played an important role in determining the ability of the firm to adjust during the economic crisis. Collective agreements at the firm level allow to better take into account the particular economic context of the firm with respect to the agreements signed at the municipality, province, regional or national level. Intuitively, we can anticipate that firms committed to a collective agreement at the firm level, can better adapt working conditions to their particular circumstances and should then better perform during the crisis period.

Finally, to test whether firms have used foreign markets as a way of adjustment to circumvent the crisis, we require information on imports and exports. This data is provided by the Balance of Payment Registries. For every year, the database contains information on whether the firm exports, imports, the amount of the exports and imports, as well as the country of destination for the exports or origin for the imports.

\footnotetext{
${ }^{7}$ The main limitation when employing these two ratios is that they are only available in our sample for firms classified as "reliable" by the CBSO according to several statistical criteria.
} 


\subsection{Sample Selection}

When working with data from the Central Balance Sheets and the Mercantile Registries, we have dropped from the sample those firms with missing or non-positive values for the number of employees, value added, intermediate inputs, physical capital, sector of activity, and year of firm creation.

Collective Agreement Registries do not contain information for all firms belonging to the database constructed from Central Balance Sheet and the Mercantile Registries. Firms for which there is no information on collective agreement are kept in the sample and are classified in the "No Agreement" category. For firms for which there is information on the type of collective agreement we implement the following merging procedure. We first consider firms from the Collective Agreement Registries being committed to an agreement at the firm level. This subsample is then merged with the Central Balance Sheet and the Mercantile Registries database using the Identifying Fiscal Code of the firm, the name of the firm or the name of the agreement. This first step allows us to identify all the firms appearing in the Central Balance Sheet and the Mercantile Registries that have signed a collective agreement at the firm level. Next, we identify firms having signed an agreement at the sectoral level. We start with sectoral agreements signed at the province level, by merging the Central Balance Sheet and the Mercantile Registries data using an indicator of the province and the economic activity branch (national classification of economic activities at 3 digits or 2 digits) to which the firm belongs. An equivalent procedure is developed to identify firms having signed a collective agreement at the municipality level, at the regional level and at the national level. Then, we merge the four databases containing firms being respectively committed to a collective agreement at the province level, at the municipality level, at the regional level and at the national level. The resulting database is merged with the base containing all firms in the Central Balance Sheet and the Mercantile Registries having signed an agreement at the firm level and with those firms for which there is no information on collective agreements. Finally, we use the Balance of Payments to add, when available, information on exports and imports.

To avoid outliers, we drop observations at the bottom and top $2.5 \%$ of the value of production, value added, capital stock, intermediate consumption and employees. ${ }^{8}$ The final sample is an unbalanced panel of 964,284 manufacturing and non-financial firms with 5,627,598 annual observations from 1995 to 2012.

\subsection{Descriptive Statistics}

In the sample, the average share of employees with temporary contracts by firm equals $22.8 \%$. However, this share has evolved from $35.5 \%$ in 1995 , to $22.9 \%$ in $2000,21.3 \%$ in 2008 , and only

\footnotetext{
${ }^{8}$ Results are robust when implementing the estimation with samples where we keep $97 \%$ and $99 \%$ of the observations.
} 


\section{$17.7 \%$ in $2012 .^{9}$}

Regarding the exporting and importing activity, $12.4 \%$ of firms in the sample develop an exporting/importing activity over the considered period. However, in 2008 there was an increase in the minimum threshold required by law to declare the export and import activity to the Balance of Payment (the new threshold was set to 45,000 euros while previously was equal 3,000 euros). If we use the 45,000 euros threshold for the entire period, $8.9 \%$ of firms in the sample develop an exporting or importing activity.

The relative shares of the different types of collective agreements vary depending of whether the merging procedure is done with the national classification of economic activities at 3 digits or at 2 digits. In the first case, among those firms with information on collective agreements, $0.2 \%$ are committed to a collective agreement at the firm level, $54.0 \%$ are committed to an agreement at the province level, $38.5 \%$ at the national level and $7.3 \%$ at the regional level (the share of firms committed to an agreement at the municipality level is negligible). ${ }^{10}$ In the second case, $0.1 \%$ of firms are committed to a collective agreement at the firm level, $75.6 \%$ are committed to an agreement at the province level, $19.0 \%$ at the national level and 5.3\% at the regional level. Although the share of firms with an agreement at the firm level is small, the percentage of workers covered by these agreements over the period equals $0.9 \%$ or $0.5 \%$, respectively, since mainly large firms sign this type of collective agreements. In the case of sectoral collective agreements, the corresponding figures for workers are $57.2 \%$ (or $76.1 \%$ ) for agreements at the province level, $35.0 \%$ (or $18.9 \%$ ) at the national level and $6.8 \%$ (or $4.5 \%$ ) at the regional level. ${ }^{11}$

\section{Measuring TFP}

The approach to measure TFP at the firm level is based on the estimation of a technology of production using an output measure and information on the amount of all the observable inputs, and then computing TFP as the residual from the estimation.

\footnotetext{
${ }^{9}$ In our sample, the share of temporary workers is computed at the firm level, so it is not directly comparable to the temporary rate obtained for the whole economy when the ratio of temporary workers over total active population is used instead. It is important though to notice that the evolution of the share of temporary workers by firm is parallel to the evolution observed for the temporary rate obtained when working with the Spanish Labor Force Survey or with administrative data from Social Security records (see figure A.1 of the appendix).

${ }^{10}$ Actually observations with agreements at the municipality level are excluded from the regression analysis.

${ }^{11}$ According to the statistics of the Spanish Ministry of Labor and Social Security, in 2008, among all firms subject to a collective agreement $0.3 \%$ of firms (and $10 \%$ of workers) were concerned by a collective agreement at the firm level while $99.7 \%$ were engaged in a collective agreement at a higher level. In particular, $66.6 \%$ were committed to a collective agreement at the province level, $27.3 \%$ at the national level and $5.7 \%$ at the regional level. Our sample then underestimates the share of workers committed to a collective agreement at the firm level.
} 


\subsection{Estimation of the production function}

As Alonso-Borrego (2010), we characterize technology as a Cobb-Douglas production function with a logarithmic specification on gross output and inputs:

$$
\begin{aligned}
& y_{i t}=\beta_{0}+\beta_{L} l_{i t}+\beta_{M} m_{i t}+\beta_{K} k_{i t}+u_{i t}, \\
& u_{i t}=\omega_{i t}+\epsilon_{i t},
\end{aligned}
$$

where, for each firm $i$ in year $t, y_{i t}$ denotes the log of gross real output; $l_{i t}$, and $m_{i t}$, denote the $\operatorname{logs}$ of labor and intermediate inputs, respectively; $k_{i t}$ is the log of the fixed capital stock, and $u_{i t}$ is a random term containing any unobserved factors affecting production. In particular, we assume that $u_{i t}$ is the sum of two terms: the random variable $\omega_{i t}$, which represents firm-specific factors that affect productivity, such as managerial ability, firm specific human capital, efficiency in the use of technology and inputs, known by the firm when choosing labor and intermediate inputs but unobserved to the econometrician; and the random variable $\epsilon_{i t}$, an idiosyncratic term that includes measurement error in output or shocks affecting output that are unknown when the firm decides the amount of inputs. The random variable $\omega_{i t}$, usually called TFP, should affect input decisions, whereas $\epsilon_{i t}$ is assumed to be independent of $\omega_{i t}$ and other inputs.

In this framework a classical endogeneity problem arises from the fact that $\omega_{i t}$ may be correlated with input choices (Griliches and Mairesse, 1995). In such a case, OLS generates inconsistent estimates of the technological parameters. The two alternative approaches to treat the endogeneity problem are the estimation including firm fixed effects and the control function method. The key assumption underlying the fixed effects approach is that unobserved firm-specific productivity shocks are invariant over time, and therefore any fixed effects transformation, such as first-differences, allows to recover the parameter estimates by means of a GMM estimation. The main caveat of this approach is - however - the potential weakness of the instruments used in the GMM. In the control function approach, proposed by Olley and Pakes (1996), the firm-specific productivity shocks are assumed to follow a Markov process and they can be recovered by means of a variable which keeps a monotonic relationship with the firm-specific shock, such as capital investment or intermediate inputs. ${ }^{12}$

Here, we use the control function method, because given the time length of our panel (19952012) we claim the assumption that the firm-specific productivity shock is constant over time might be unrealistic.

Olley and Pakes (1996) assume $\omega_{i t}$ follows a first order Markov process, without requiring any parametric assumption. Instead of instrumenting the endogenous regressors, they include other decision variables - such as investment - monotonically related with the productivity shock. Formally, they assume that $k$ is a quasi-fixed input, and that there is some time-to-build, that is, investment installed in period $t$ only becomes productive at $t+1$. Under this assumption,

\footnotetext{
${ }^{12}$ For a complete discussion of the alternative approaches see, for example, Ackerberg et al. (2007) or Aguirregabiria (2009).
} 
the investment demand function $i_{i t}=i\left(\omega_{i t}, k_{i t}\right)$ can be inverted to obtain the unobserved productivity as a non parametric function of investment and capital, $\omega_{i t}=h_{t}\left(i_{i t}, k_{i t}\right)$. However, the limitation when using investment as proxy is that estimation must be restricted to the sub-sample of observations with positive investment in order to fulfill the monotonicity condition. Levinsohn and Petrin (2003) propose to use intermediate inputs, which (unlike investment) are likely to be nonzero at all times. In this case, the materials' demand function $m_{i t}=m\left(\omega_{i t}, k_{i t}\right)$ is inverted to obtain $\omega_{i t}=\omega_{t}\left(m_{i t}, k_{i t}\right)$, under monotonicity plus some additional assumptions. ${ }^{13}$

In general, Levinsohn and Petrin's method estimates the intermediate inputs elasticity, $\beta_{M}$. But they point out that under perfect competition, a separable production function, ad some additional assumption, equation (2) also applies to value added, $v_{i t}$, suppressing materials on the right-hand side. ${ }^{14}$ The equation becomes:

$$
\begin{aligned}
v_{i t} & =\beta_{0}+\beta_{L} l_{i t}+\beta_{K} k_{i t}+\omega_{t}\left(m_{i t}, k_{i t}\right)+\epsilon_{i t} \\
& =\beta_{L} l_{i t}+\phi_{t}\left(m_{i t}, k_{i t}\right)+\epsilon_{i t},
\end{aligned}
$$

where $\phi_{t}\left(m_{i t}, k_{i t}\right)=\beta_{0}+\beta_{K} k_{i t}+\omega_{t}\left(m_{i t}, k_{i t}\right)$. In practice, we approximate $\phi_{t}\left(m_{i t}, k_{i t}\right)$ by means of a third-order polynomial in $m_{i t}$ and $k_{i t}$. Then equation (3) is estimated by OLS in a first stage to get the estimated coefficient $\hat{\beta}_{L}$.

A second stage of the routine identifies $\beta_{K}$. This stage begins by computing the estimated value $\hat{\phi}_{i t}=v_{i t}-\hat{\beta}_{L} l_{i t}$. Then, for any candidate value $\beta_{K}^{*}$, we can compute (up to a scalar constant) a prediction for $\omega_{t}$ for all periods using $\hat{\omega}_{i t}=v_{i t}-\hat{\beta}_{L} l_{i t}-\beta_{K}^{*} k_{i t}=\hat{\phi}_{i t}-\beta_{K}^{*} k_{i t}$.

Assume that productivity, $\omega_{i t}$, is governed by a first-order Markov process,

$$
\omega_{i t}=E\left[\omega_{i t} \mid \omega_{i t-1}\right]+\zeta_{i t},
$$

where $\zeta_{i t}$ is an innovation to productivity that is uncorrelated with $k_{i t}$, but not necessarily to $l_{i t}$. Now, a consistent (nonparametric) approximation to $E\left[\omega_{i t} \mid \omega_{i t-1}\right]$ is given by the predicted values from the regression

$$
\hat{\omega}_{i t}=\gamma_{0}+\gamma_{1} \omega_{i t-1}+\gamma_{2} \omega_{i t-2}+\gamma_{3} \omega_{i t-3}+\xi_{i t},
$$

which Levinsohn and Petrin $(2003)$ call $E\left[\widehat{\omega_{i t} \mid \omega_{i t}-1}\right]$. Given $\hat{\beta}_{L}, \beta_{K}^{*}$, and $E\left[\widehat{\omega_{i t} \mid \omega_{i t}-1}\right]$, they write the sample residual of the production function as

$$
\epsilon_{i t}+\zeta_{i t}=v_{i t}-\hat{\beta}_{L} l_{i t}-\beta_{K}^{*} k_{i t}-E\left[\widehat{\omega_{i t} \mid \omega_{i t}-1}\right] .
$$

Then, the estimate $\hat{\beta}_{K}$ is defined as the solution to

$$
\min _{\beta} \sum_{i} \sum_{t}\left(v_{i t}-\hat{\beta}_{L} l_{i t}-\beta_{K}^{*} k_{i t}-E\left[\widehat{\omega_{i t} \mid \omega_{i t}}-1\right]\right)^{2} .
$$

Since estimation involves the use of predicted values, appropriate standard errors of the estimated coefficients $\hat{\beta}_{L}$ and $\hat{\beta}_{K}$ are computed by bootstrap methods.

\footnotetext{
${ }^{13}$ The original justification for this alternative choice is that, while most firms report positive expenditure on materials every year, a much lower proportion undertake investment every year. In our specific case, we simply do not have information on investment in the data.

${ }^{14}$ See Levinsohn and Petrin (2003), appendix B.
} 


\section{Estimation results of the production function}

Our dependent variable is the log of value added. We have used three alternative estimation procedures: ordinary least squares (OLS), fixed effects (FE) and Levinsohn and Petrin (LP). For our LP estimates, we have approximated the function $\phi_{t}\left(m_{i t}, k_{i t}\right)$ by means of a third-order polynomial approximation in $m_{i t}$ and $k_{i t}$. To allow for differences across industries, we estimate a production function for each industry separately. We consider a 10 sector classification: Agriculture, Extractive, Manufacture, Energy, Construction, Sales, Transport, Tourism, EducationHealth, Non-financial Services. First, we report the OLS, FE, and LP estimation results of the technological parameters for each of the 10 groups. In addition, we consider an extended version of the production function in which the labor input is decomposed between permanent labor (that is, number of employees with indefinite positions) or temporary labor (workers with fixed-term contracts).

\subsection{Estimation results}

Table 1 reports OLS, FE, and LP estimation results of the technological parameters. We can see that the LP estimated coefficients for labor and capital are lower than the corresponding OLS estimates. The evidence reported is coherent with the successful bias correction provided by the control function approach. ${ }^{15}$ Nevertheless, the magnitude of the capital coefficients seems to be too low in some cases. ${ }^{16}$ This low estimated elasticities are though consistent with the estimations provided by Dolado et al. (2011) or Doraszelski and Jaumandreu (2013) on a panel of Spanish manufacturing industries. ${ }^{17}$

Next, we split the estimation period into two sub-periods, 1995-2007 and 2008-2012, and estimate one different production function for each. We implement this analysis by sub-periods for two reasons: on the one hand, in 2007 there was a major change in the National Accountancy System that may have induced a break in the time series. On the other hand, the economic crisis started in 2008, so the distinction by sub-periods allows us to evaluate the potential variation in the technological coefficients of the production function during the crisis.

Table 2 reports the LP estimates for both sub-periods. For the first sub-period we find essentially the same results as in table 1. For the crisis period, however, we find that the coefficient associated with capital decreases heavily in most sectors.

\footnotetext{
${ }^{15}$ Table A.1 of the appendix reports LP estimation results of the technological parameters in two bigger samples: one in which we drop a $3 \%$ of the extreme values of production, value added, capital stock, intermediate consumption and employees; and another sample in which we have dropped only a 1\%. Although results do not change substantially, we observe that estimates for the elasticity of capital increase slightly when the percentage of extreme values excluded from the sample decreases.

${ }^{16}$ Table A.2 of the appendix shows estimates for different definitions of capital in a small sub-sample of firms for which several measures for capital are available. It seems that in case of considering the tangible capital at market value instead of book value, estimates for the capital coefficients would be even smaller.

${ }^{17}$ Due to their econometric specification, Doraszelski and Jaumandreu (2013) estimate though a lower elasticity of the production function with respect to labor.
} 
Table 1: Comparison of OLS, FE, and LP estimators (whole period).

\begin{tabular}{lcccccc}
\hline \hline & \multicolumn{2}{c}{ OLS } & \multicolumn{2}{c}{ FE } & \multicolumn{2}{c}{ LP } \\
\cline { 2 - 7 } & $\beta_{L}$ & $\beta_{K}$ & $\beta_{L}$ & $\beta_{K}$ & $\beta_{L}$ & $\beta_{K}$ \\
\hline Agriculture & 0.7042 & 0.1679 & 0.3675 & 0.1612 & 0.5507 & 0.0645 \\
Extractive & $(0.0044)$ & $(0.0026)$ & $(0.0039)$ & $(0.0028)$ & $(0.0041)$ & $(0.0068)$ \\
& 0.8035 & 0.2238 & 0.6473 & 0.1874 & 0.5862 & 0.1415 \\
Manufacture & $(0.0151)$ & $(0.0088)$ & $(0.0121)$ & $(0.0083)$ & $(0.0178)$ & $(0.0195)$ \\
& 0.8709 & 0.1602 & 0.6387 & 0.1341 & 0.6824 & 0.0627 \\
Energy & $(0.0018)$ & $(0.0010)$ & $(0.0012)$ & $(0.0007)$ & $(0.0019)$ & $(0.0017)$ \\
& 0.7507 & 0.2321 & 0.5317 & 0.1575 & 0.5657 & 0.1064 \\
Construction & $(0.0089)$ & $(0.0059)$ & $(0.0094)$ & $(0.0056)$ & $(0.0106)$ & $(0.0138)$ \\
Sales & 0.7842 & 0.1555 & 0.6802 & 0.0927 & 0.5909 & 0.1061 \\
Transport & $(0.0015)$ & $(0.0009)$ & $(0.0013)$ & $(0.0008)$ & $(0.0016)$ & $(0.0013)$ \\
Tourism & 0.8500 & 0.1493 & 0.5618 & 0.1143 & 0.6445 & 0.0748 \\
Education-Health & $(0.0014)$ & $(0.0008)$ & $(0.0010)$ & $(0.0005)$ & $(0.0015)$ & $(0.0012)$ \\
Other non-financial services & 0.7734 & 0.1603 & 0.5523 & 0.0940 & 0.6140 & 0.0806 \\
& $(0.0014)$ & $(0.0008)$ & $(0.0012)$ & $(0.0006)$ & $(0.0015)$ & $(0.0015)$ \\
\hline & $0.0030)$ & $(0.0019)$ & $(0.0021)$ & $(0.0013)$ & $(0.0037)$ & $(0.0032)$ \\
& 0.8572 & 0.1376 & 0.4827 & 0.1057 & 0.4662 & 0.0838 \\
& $(0.0024)$ & $(0.0012)$ & $(0.0017)$ & $(0.0011)$ & $(0.0033)$ & $(0.0021)$ \\
& 0.7651 & 0.1419 & 0.5172 & 0.0947 & 0.5701 & 0.0766 \\
& $(0.0036)$ & $(0.0020)$ & $(0.0025)$ & $(0.0014)$ & $(0.0038)$ & $(0.0038)$ \\
& 0.1815 & 0.5884 & 0.1665 & 0.6695 & 0.0939 \\
& & & & & &
\end{tabular}

Notes: Observations $=5,627,598$. Bootstrap standard errors in parentheses (100 replications). 
Table 2: LP estimates (sub-periods).

\begin{tabular}{lcccc}
\hline \hline & \multicolumn{2}{c}{$1995-2007$} & \multicolumn{2}{c}{$2008-2012$} \\
\cline { 2 - 5 } & $\beta_{L}$ & $\beta_{K}$ & $\beta_{L}$ & $\beta_{K}$ \\
\hline Agriculture & 0.5352 & 0.1016 & 0.5742 & 0.0408 \\
Extractive & $(0.0058)$ & $(0.0112)$ & $(0.0061)$ & $(0.0110)$ \\
Manufacture & 0.5572 & 0.1274 & 0.6142 & 0.0636 \\
& $(0.0233)$ & $(0.0158)$ & $(0.0226)$ & $(0.0391)$ \\
Energy & 0.6650 & 0.0579 & 0.7071 & 0.0579 \\
Construction & $(0.0031)$ & $(0.0022)$ & $(0.0026)$ & $(0.0033)$ \\
Sales & 0.5796 & 0.0842 & 0.5434 & 0.1292 \\
Transport & $(0.0109)$ & $(0.0150)$ & $(0.0160)$ & $(0.0235)$ \\
Tourism & 0.5555 & 0.0865 & 0.6111 & 0.0594 \\
Education-Health & $(0.0017)$ & $(0.0019)$ & $(0.0023)$ & $(0.0030)$ \\
Other non-financial services & 0.6317 & 0.0802 & 0.6640 & 0.0629 \\
& $(0.0019)$ & $(0.0013)$ & $(0.0017)$ & $(0.0026)$ \\
Observations & 0.6361 & 0.0974 & 0.7359 & 0.0629 \\
\hline Notes Botany & $(0.0020)$ & $(0.0018)$ & $(0.0021)$ & $(0.0023)$ \\
\hline & $3.526,396$ & $2,101,202$ \\
\hline
\end{tabular}

Notes: Bootstrap SE in parentheses (100 replications). 
Finally, table 3 reports LP estimation results for a production function with permanent and temporary labor, $L_{p}$ and $L_{t}$, respectively. We can see that the estimated coefficients for temporary labor are always lower than the corresponding estimates for permanent workers. ${ }^{18}$ Our results are consistent with the estimations of Dolado et al. (2011). Using a data set of Spanish manufacturing firms, Dolado et al. (2011) estimate the elasticity of the production function with respect to temporary labor, permanent labor, intermediate materials and capital, imposing constant returns to scale (CRS). In our case, we do not impose CRS and our database covers both manufacturing and non-financial firms, which implies that we have a different industrial classification than in Dolado et al. (2011). Coefficients estimates associated with capital, permanent and temporary labor for agriculture, extractive, energy and manufacturing industries are of the same order of magnitude as the estimations provided by Dolado et al. (2011), which makes us confident in our results. $^{19}$

\subsection{Evolution of the estimated TFP}

Once the technological parameters have been obtained, we recover our predicted TFP at the firm level by plugging the estimated coefficients in the production function:

$$
\widehat{T F P_{i t}} \equiv \exp \left(\widehat{\omega}_{i t}\right)=\exp \left(v_{i t}-\hat{\beta}_{0}-\hat{\beta}_{L} l_{i t}-\hat{\beta}_{K} k_{i t}\right)
$$

where we have replaced the estimated technological parameters for those corresponding to the economic activity to which firm $i$ belongs.

Since TFP is estimated as a residual, we have different TFP estimations for each of the different model specifications and sub-samples that we consider in subsection 5.1. ${ }^{20}$

Figure 4 compares the evolution of the average TFP growth at the firm level (left hand side panel), with that at the aggregate level (right panel). ${ }^{21}$ We can see that the growth rate of the average firm TFP has been continuously negative and decreasing since the beginning of the crisis (between 2010 and 2012 there is a slight increase in the growth rate, though it remains below $-5 \%)$. For aggregate TFP, the growth rate is negative but closer to zero during the crisis period. Moreover, in 2012 the growth rate becomes positive. Thus, composition effects seem to have played a major role in explaining the better performance of TFP at the macro level. That is, firms having a relatively larger size within the total population of firms have displayed a rising

\footnotetext{
${ }^{18}$ Indeed, the differences between the LP coefficients associated with permanent and temporary labor are all statistically significant at $1 \%$ level.

${ }^{19}$ Coefficients associated with permanent labor seem slightly higher in the agriculture industry for Dolado et al. (2011), but this may be explained by the fact that their classification of agriculture includes also industrial machinery.

${ }^{20}$ Figure 4 reports estimates for the cases where production coefficients are estimated: (i) for the whole period; (ii) by sub-periods (1995-2007 versus 2008-2012); and (iii) for the whole period in a balanced panel of firms. With respect to the different specifications, in general we do not observe much of a difference in the estimated TFP. Given that, for our regressions we will use the estimated TFP obtained from results in Table 1.

${ }^{21}$ Aggregated figures are obtained by aggregating firms using employment weights.
} 
Table 3: LP estimates (permanent vs. temporary labor).

\begin{tabular}{lccc}
\hline \hline & $\beta_{L p}$ & $\beta_{L t}$ & $\beta_{K}$ \\
\hline Agriculture & 0.1363 & 0.1125 & 0.0889 \\
Extractive & $(0.0020)$ & $(0.0011)$ & $(0.0079)$ \\
Manufacture & 0.1547 & 0.0601 & 0.1715 \\
& $(0.0105)$ & $(0.0038)$ & $(0.0208)$ \\
Energy & 0.2755 & 0.0715 & 0.0937 \\
& $(0.0017)$ & $(0.0004)$ & $(0.0022)$ \\
Construction & 0.2179 & 0.0885 & 0.1318 \\
Sales & $(0.0071)$ & $(0.0021)$ & $(0.0128)$ \\
Transport & 0.1414 & 0.1062 & 0.1454 \\
Tourism & $(0.0008)$ & $(0.0005)$ & $(0.0016)$ \\
& 0.2657 & 0.0690 & 0.0987 \\
Education-Health & $(0.0011)$ & $(0.0003)$ & $(0.0012)$ \\
Other non-financial services & 0.2245 & 0.0775 & 0.1393 \\
& $(0.0023)$ & $(0.0007)$ & $(0.0033)$ \\
& 0.1164 & 0.0465 & 0.1135 \\
& $(0.0012)$ & $(0.0004)$ & $(0.0014)$ \\
\hline
\end{tabular}

Notes: Obs $=5,627,598$. Bootstrap SE in parentheses (100 replications). 
behavior of TFP during the crisis that has partially compensated the bad TFP performance of the vast majority of (smaller) firms.

Figure 4: Estimated TFP growth (non-weighted and weighted averages, \%).
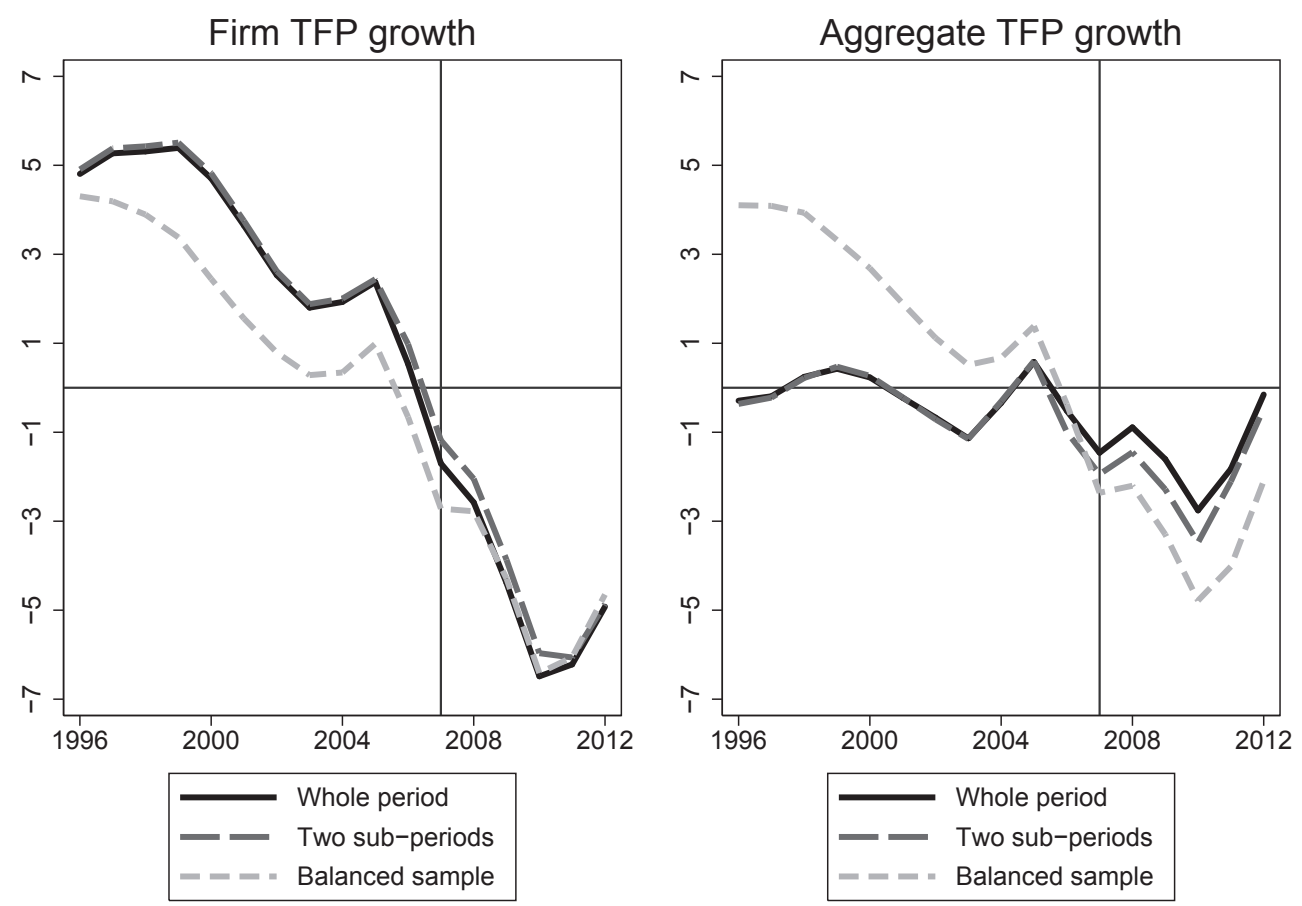

Notes: Firm TFP=simple average across firms; Aggregate TFP=firms aggregated using employment weights. Five years moving average of annual growth rates.

Moreover, if we look within the balanced sample of firms (dotted light gray lines, representing firms that are present through the whole period) the evolution of aggregate TFP is not so different from that of the average firm. The difference in behavior between the balanced sample (light gray) and unbalanced sample (black) indicates that some high productive firms were nipped in the bud but recession especially nipped off some big firms with low TFP performance who were present at the beginning of the period. In addition, the figure shows that large survival firms are more productive than the average firm and, even more, large new firms that have entered during or after the crisis are especially productive.

After computing TFP at the firm level, the longitudinal variation year-by-year can be exploited to study how the adjustment margins of the firm, measured through the share of temporary contracts, the type of collective agreement and the imports/exports information, relate to the estimated TFP. 


\section{Adjustment margins}

In this section we quantify the relationship between firm TFP and some margins that companies have in order to adjust to changing economic conditions. More precisely, we consider two distinct types of adjustment margins. On the one hand, input adjustment margins concern the type of contract proposed to workers or the type of collective agreement. On the other hand, the output adjustment margin concerns the markets where firms sell their products.

First, we consider the collective bargaining system, as it is a fundamental mechanism for explaining the working of the Spanish labor market. The vast majority of workers in Spain see their wage (and, generally, working conditions) set in collective bargaining between trade union and employers' representatives. The system is based in two main principles. On the one hand, the Principle of statutory extension claims that any minimum condition established in a collective agreement at higher than firm level apply to every worker forming part of the corresponding geographical and/or industry unit. On the other, the Principle of ultra-activity imposes that any agreement remains valid after its expiry, if it has not been renewed. Although collective agreements at the firm level allow to better take into account the particular economic context of the firm, even in that case - due to the two previous principles - it is very difficult for a firm to easily adjust to adverse economic conditions. ${ }^{22}$

Alternatively, firms can adjust their situation internally by adjusting the number of workers. In the particular case of Spain, firms have massively opted to destroy temporary positions.

Finally, it is well documented in the literature that exporting firms display better productivity performance. By facing international competition, these firms are obliged to be at the efficiency frontier if they want to survive. During a crisis period in a particular country, exporting firms may circumvent the bad economic conditions of their own country.

\subsection{Estimation results}

Formally, we regress $\log$ TFP for firm $i$ in year $t, \widehat{\omega}_{i t}$, on a set of variables including input and output adjustment margins:

$$
\widehat{\omega}_{i t}=\gamma_{a} a_{i t}+\gamma_{z} z_{i t}+\eta_{i}+\eta_{t}+\kappa_{i t}
$$

where $a_{i t}$ stands for the adjustment margins (the type of collective agreement, the share of workers with temporary contracts, an indicator of being importer and/or exporter), $z_{i t}$ includes dummies on the firm's size, age, region of location, economic sector, and debt structure, $\eta_{i}$ and $\eta_{t}$ are firm fixed effects and time dummies, respectively, and $\kappa_{i t}$ stands for the random error term.

Similarly to Alonso-Borrego (2010), it is important to note that given the lack of a theoretical model to justify the set of explanatory variables, our estimates are capturing partial correlations, which cannot be given a causal interpretation. The evidence provided can only help to understand

\footnotetext{
${ }^{22}$ See Izquierdo et al. (2003) for details.
} 
what variables are related to TFP, but further research is needed to support a causal interpretation of the estimated effects.

Table 4 reports fixed effects estimates of the correlation between the adjustment margins and firm's TFP. The first column considers the whole sample of firms and the third column adds financial ratios. The debt ratios are only available in the sample for those firms classified as reliable by the CBSO according to several statistical criteria. Thus, to assess the possible existence of sample selection, column 2 considers the sub-sample of firms for which we have information on the financial ratios. Finally, column 4 considers financial ratios as well as the tighter definition of the exporting/importing activity of firms.

Table 4: Firm fixed effects regression of estimated TFP.

\begin{tabular}{|c|c|c|c|c|}
\hline & $\begin{array}{c}\text { Full } \\
\text { sample }\end{array}$ & $\begin{array}{l}\text { Sample with } \\
\text { financial data }\end{array}$ & $\begin{array}{l}\text { Controlling for } \\
\text { financial data }\end{array}$ & $\begin{array}{l}\text { Tighter definition } \\
\text { importer/exporter }\end{array}$ \\
\hline Share of temporary workers & $\begin{array}{c}-0.0511^{* * *} \\
(0.0014)\end{array}$ & $\begin{array}{c}-0.0373^{* * *} \\
(0.0022)\end{array}$ & $\begin{array}{c}-0.0372^{* * *} \\
(0.0021)\end{array}$ & $\begin{array}{c}-0.0372^{* * *} \\
(0.0021)\end{array}$ \\
\hline Importer/exporter & $\begin{array}{c}0.0865^{* * *} \\
(0.0012)\end{array}$ & $\begin{array}{c}0.0603^{* * *} \\
(0.0015)\end{array}$ & $\begin{array}{c}0.0631^{* * *} \\
(0.0015)\end{array}$ & \\
\hline Importer/exporter (2008 threshold) & & & & $\begin{array}{c}0.0907^{* * *} \\
(0.0019)\end{array}$ \\
\hline Firm agreement & $\begin{array}{l}0.122^{* * *} \\
(0.0168)\end{array}$ & $\begin{array}{c}0.0753^{* * *} \\
(0.0198)\end{array}$ & $\begin{array}{c}0.0758^{* * *} \\
(0.0199)\end{array}$ & $\begin{array}{c}0.0756^{* * *} \\
(0.0199)\end{array}$ \\
\hline Province agreement & $\begin{array}{c}-0.0254^{* * *} \\
(0.0019)\end{array}$ & $\begin{array}{c}-0.0192^{* * *} \\
(0.0024)\end{array}$ & $\begin{array}{c}-0.0190^{* * *} \\
(0.0024)\end{array}$ & $\begin{array}{c}-0.0190^{* * *} \\
(0.0024)\end{array}$ \\
\hline Regional agreement & $\begin{array}{c}-0.0273^{* * *} \\
(0.0034)\end{array}$ & $\begin{array}{c}-0.0343^{* * *} \\
(0.0044)\end{array}$ & $\begin{array}{c}-0.0326^{* * *} \\
(0.0044)\end{array}$ & $\begin{array}{c}-0.0321^{* * *} \\
(0.0044)\end{array}$ \\
\hline National agreement & $\begin{array}{c}-0.0065^{* * *} \\
(0.0019)\end{array}$ & $\begin{array}{l}-0.0039 \\
(0.0025)\end{array}$ & $\begin{array}{l}-0.0034 \\
(0.0025)\end{array}$ & $\begin{array}{l}-0.0033 \\
(0.0025)\end{array}$ \\
\hline Debt ratio & & & $\begin{array}{c}-0.0464^{* * *} \\
(0.0006)\end{array}$ & $\begin{array}{c}-0.0463^{* * *} \\
(0.0006)\end{array}$ \\
\hline Short term ratio & & & $\begin{array}{c}-0.0050^{* * *} \\
(0.0005)\end{array}$ & $\begin{array}{c}-0.0049^{* * *} \\
(0.0005)\end{array}$ \\
\hline 10-19 employees & $\begin{array}{c}0.0243^{* * *} \\
(0.0014)\end{array}$ & $\begin{array}{c}0.0122 * * * \\
(0.0017)\end{array}$ & $\begin{array}{c}0.0113 * * * \\
(0.0017)\end{array}$ & $\begin{array}{c}0.0108^{* * *} \\
(0.0017)\end{array}$ \\
\hline 20-49 employees & $\begin{array}{c}0.0503^{* * *} \\
(0.0025)\end{array}$ & $\begin{array}{l}0.0395^{* * *} \\
(0.0031)\end{array}$ & $\begin{array}{c}0.0397 * * * \\
(0.0031)\end{array}$ & $\begin{array}{c}0.0383^{* * *} \\
(0.0031)\end{array}$ \\
\hline$>50$ employees & $\begin{array}{l}-0.0015 \\
(0.0058)\end{array}$ & $\begin{array}{c}0.0174 * * * \\
(0.0065)\end{array}$ & $\begin{array}{c}0.0183^{* * *} \\
(0.0065)\end{array}$ & $\begin{array}{l}0.0159^{* *} \\
(0.0065)\end{array}$ \\
\hline Constant & $\begin{array}{c}3.292^{* * *} \\
(0.096)\end{array}$ & $\begin{array}{c}3.256^{* * *} \\
(0.107) \\
\end{array}$ & $\begin{array}{c}3.258^{* * *} \\
(0.109) \\
\end{array}$ & $\begin{array}{c}3.263^{* * *} \\
(0.108)\end{array}$ \\
\hline Observations & $5,618,004$ & $2,862,843$ & $2,862,843$ & $2,862,843$ \\
\hline
\end{tabular}


Several conclusions can be drawn from the estimations reported in table 4. First, we find that the share of temporary workers is negatively correlated with TFP performance during the considered period, 1995-2012. Firms with a larger share of temporary workers are associated with poorer performance in terms of TFP. Second, firms having signed a collective agreement at the firm level perform better, in terms of TFP, than firms subject to a sectoral agreement. Third, being an importer/exporter positively correlates with TFP performance, whatever the definition we adopt for this indicator. Fourth, a negative and significant correlation arises between the debt ratio and TFP. Similarly, the short term debt ratio negatively correlates with TFP. Finally, firm's size positively correlates with TFP performance.

\subsection{Time variation}

In order to assess how the relationship of adjustment margins with TFP varies over time, we also allow the coefficients on the adjustment margins to vary year by year. The time variation of coefficients associated with the share of temporary workers, the firm agreement level and the use of foreign markets is displayed in figure 5. As previously, we control for time dummies, debt ratios and for indicators of firm's size, age, region and sector. ${ }^{23}$

Figure 5: Time variation in adjustment margins.

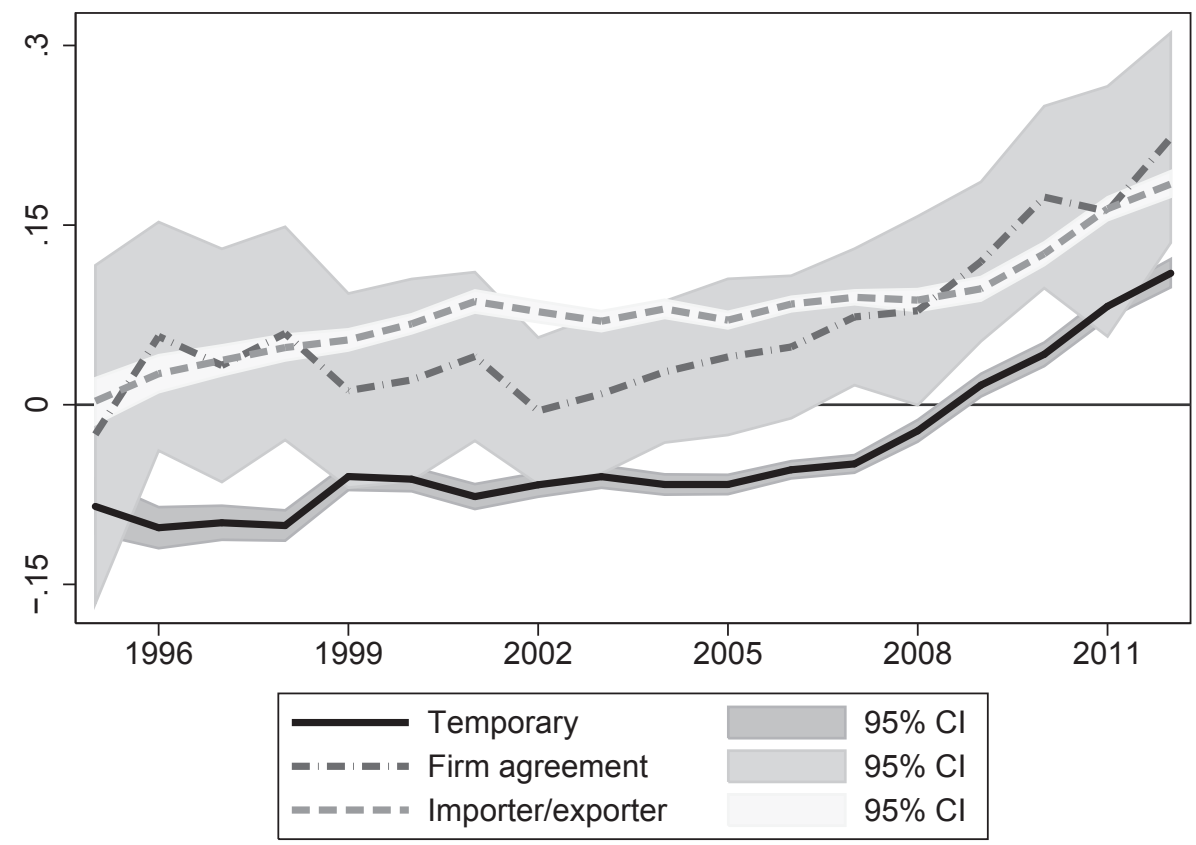

Notes: Estimates from firm fixed effect regressions of TFP on firm's age, size, region, sector, debt ratios, adjustment indicators, and interactions of these latter with time dummies.

\footnotetext{
${ }^{23}$ In practice, we add to every coefficient associated with the interacted variable the coefficient of the time dummy of the corresponding year. This allows us to obtain the differentiated relation between TFP and the explanatory variable year by year.
} 
Figure 5 shows that firms committed to a collective agreement at the firm level perform better than the average in TFP terms since the beginning of the crisis, although the estimated effect is imprecise. Similarly, firms using external markets perform better than average since the late nineties. On the contrary, firms with a larger share of temporary workers perform worse in TFP terms during years preceding the crisis. This situation is though reversed from 2009. Firms with a larger share of temporary workers perform increasingly better during the period 2009-2012.24 This sign reversal, could be explained by the massive destruction of temporary jobs that yielded a selection process. It appears that highly productive firms are now quickly hiring temporary workers, and it is likely that these new workers have different characteristics from those occupying temporary positions during years preceding the crisis. Indeed, administrative records show that the proportion of high-skilled workers has increased among temporary employees since 2007 (see figure A.1 of the appendix).

\subsection{Robustness check: TFP growth rate}

Up to now, we have evaluated the correlation between adjustment margins and the level of firm TFP. However, the "Spanish Productivity Puzzle" refers to the different evolution of the productivity growth displayed by Spain relative to its European neighbors and the US. In this section then we seek to analyze how input adjustment margins (represented by the share of temporary workers and the type of collective agreement) and output adjustment margins (proxied by the fact of being an importer/exporter) may have influenced TFP growth. To do so, we simply modify the previous regression to introduce the yearly variation of the log of our estimated TFP for firm i, $\left(\Delta \widehat{\omega_{i t}}\right)$, as the dependent variable.

Estimation results are provided in table A.3 of the appendix. As previously, the first column considers the whole sample of firms and the third column adds financial ratios. Column 2 considers the sub-sample of firms for which we have information on the financial ratios, and column 4 considers financial ratios as well as the tighter definition of the exporting/importing activity of firms. Results are fairly consistent with previous estimates on TFP levels. The share of temporary workers is negatively correlated to TFP growth, while being an importer/exporter positively correlates with TFP growth, whatever the definition of importer/exporter we adopt. Now, however, the type of the collective agreement does not display any significant relationship with TFP growth.

Finally, we allow the coefficients of the adjustment margins to vary year by year, in order to assess the differentiated relationship of these variables with respect to TFP growth over time.

\footnotetext{
${ }^{24}$ We have also implemented a fixed effects estimation of the correlation between the adjustment margins and firm's TFP in the two sub-periods, 1995-2007 and 2008-2012. We find that being an importer/exporter positively correlates with TFP performance in both sub-periods. Firms having signed a collective agreement at the firm level or at the national level perform better, in terms of TFP, during the expansion period. During the crisis, the situation is modified. Only firms committed to a national agreement perform relatively better. The share of temporary workers negatively correlates with TFP from 1995 to 2007, while after 2008 the correlation is positive. Estimates are available upon request.
} 
Figure A.2 of the appendix compares the time varying relationship between importing/exporting firms, the share of temporary workers and the evolution of TFP in levels (left hand side panel) and in growth terms (right hand side panel). As before, importing/exporting firms out-perform the rest over the whole period but even more after 2008. Concerning the share of temporary workers, when considering TFP growth, the negative since becomes insignificant during the crisis period.

\section{Conclusions}

This paper seeks to gain insights on the apparently puzzling behavior of labor productivity in Spain during the economic crisis. While Spain had traditionally under-performed its European counterparts in terms of productivity, the trend is reversed during the crisis. Since 2007 Spain displays growth rates of aggregate labor productivity which are above France, Germany, the UK and the US. Our analysis shows that this behavior of Spanish labor productivity results from a composition effect, with larger firms displaying a better TFP performance during the crisis.

Our estimates suggest that, while the share of temporary workers is negatively correlated to TFP during the whole period 1995-2012, when we focus on the crisis period, the sign of this correlation is reversed. Again, compositional changes in the population of temporary workers during the crisis may justify this sign reversal. On the other hand, firms having committed to a collective agreement at the firm level display better TFP performance than firms engaged in sectoral collective agreements over the whole period. Firms that are importers or exporters also display a better TFP behavior than average.

In sum, the recent upsurge in Spanish productivity may not be explained entirely by permanent factors, as average TFP has decreased during the crisis period. Instead, the recent improvement in labor productivity results from massive jobs destruction, and an increased weight of large firms displaying better TFP performance. This second effect, however, might be permanent to some extent.

\section{References}

[1] Ackerberg, D., L. Benkard, S. Berry, and A. Pakes (2007), "Econometric Tools for Analyzing market Outcomes", in J. Heckman and E. Leamer (eds.), Handbook of Econometrics, Vol.6.

[2] Aguirragabiria, V.(2009), "Econometric Issues and Methods in the Estimation of Production Functions", MPRA Paper 15973, University Library of Munich, Germany.

[3] Aguirragabiria, V., and C. Alonso-Borrego (2009), "Labor Contracts and Flexibility: Evidence from a Labor Market Reform in Spain", Universidad Carlos III Working Paper 09-18.

[4] Almunia, M., and D. López-Rodríguez (2012), "The Efficiency Costs of Tax Enforcement: Evidence from a Panel of Spanish Firms", mimeo. 
[5] Alonso-Borrego, C. (2010), "Firm Behavior, Market Deregulation and Productivity in Spain", Bank of Spain Working Paper 1035.

[6] Bassanini, A., L. Nunziata, and D. Venn (2009), "Job Protection Legislation and Productivity Growth in OECD Countries", Economic Policy, April, 349-402.

[7] Black, S., and L. Lynch (2001), "How to compete: the impact of workplace practices and information technology on productivity", Review of Economics and Statistics 83:434-445.

[8] Black, S., and L. Lynch (2004), "The New Economy, understanding the role of workplace practices", Economic Journal 114:97-116.

[9] Boldrin, M., J.I. Conde-Ruiz, and J. Diaz-Gimenez (2010), "Eppur si Muove! Spain: Growing without a Model ", FEDEA-WP 11.

[10] Bresnahan, T.F., E. Brynjolfsson, and L.M. Hitt (2002), "Information Technology, Workplace organization, and the Demand for skilled Labor: Firm-Level Evidence", Quarterly Journal of Economics 117 (1): 339-376.

[11] Dolado, J., S. Ortigueira, and R. Stuccchi, (2011), "Does dual employment protection affect TFP? Evidence from Spanish manufacturing firms", IZA Discussion Paper 3832.

[12] Doraszelski, U. and J. Jaumandreu (2013), "R\&D and productivity: Estimating endogenous productivity", Review of Economis Studies 80: 1338-1383.

[13] Fariñas, J.C., and S. Ruano (2004), "The dynamics of Productivity : A Decomposition Approach Using Distribution Functions", Small Business Economics 22 (3-4): 237-251.

[14] Gonzalez, X., and D. Miles-Touya (2012), "Labor market rigidities and economic efficiency: Evidence from Spain", Labour Economics 19 (6): 833-845.

[15] Griliches, Z., and J. Mairesse (1995), "Production Functions: The Search for Identification", NBER Working Paper 5067.

[16] Huergo, E., and J. Jaumandreu (2004), "How does probability of innovation change with firm age?", Small Business Economics 22 (3-4): 193-207.

[17] Izquierdo, M., E. Moral, and A. Urtasun (2003), "Collective bargaining in Spain: an individual data analysis", Bank of Spain Ocassional Paper 0302.

[18] Javorcik, B.S. (2004), "Does Foreign Direct Investment Increase the Productivity of Domestic Firms?", American Economic Reviw 94 (3): 605-627.

[19] Jimeno, J.F., and R. Sánchez-Mangas (2006), "La productividad de la Economía Española" in La dinámica de la productividad española, edited by J. Segura, 105-127. Fundacion Ramón Areces. 
[20] Levinsohn, J., and A. Petrin (2003), "Estimating Production Functions Using Inputs to Control for Unobservables", Review of Economic Studies 70:317-342.

[21] Lopez-Garcia, P., S. Puente, and A.L. Gomez (2007), "Firm Productivity dynamics in Spain", Bank of Spain Working Paper 739.

[22] Martinez, D., J. Rodriguez, and J.L. Torres (2008), "The Productivity Paradox and the New Economy: The Spanish case", Journal of Macroeconomics 30:1569-1586.

[23] Mas, M., and J. Quesada (2006), "The role of ICT in Spanish Productivity Slowdown", Fundacion BBVA Working Paper 5.

[24] Mora-Sanguinetti, J., and A. Fuentes (2012), "An Analysis of Productivity Performance in Spain Before and During the Crisis: Exploring the Role of Institutions", OCDE Working Paper 973.

[25] Olley, G. S, and A. Pakes (2006), "The Dynamics of Productivity in the Telecommunications Equipment Industry", Econometrica 64:1263-1297.

[26] Ortega, E. and J. Peñalosa (2013), "Algunas Reflexiones sobre la Economia Española tras Cinco Años de Crisis", Banco de España WP 1304.

[27] Pilat, D. (2005), "Spain's Productivity Performance in International Perspective", OECD Workshop on Productivity, Madrid.

[28] Sargent, T.C. and E.R. Rodriguez (2001), "Labour or Total Factor Productivity: Do We Need to Choose?", Departement of Finance Working Paper 2001-04, Economic Studies and Policy Analysis Division. 


\section{A Appendix}

Table A.1: LP estimates (bigger samples).

\begin{tabular}{lcccc}
\hline \hline & \multicolumn{2}{c}{$97 \%$ of the original sample } & \multicolumn{2}{c}{$99 \%$ of the original sample } \\
\cline { 2 - 5 } & $\beta_{L}$ & $\beta_{K}$ & $\beta_{L}$ & $\beta_{K}$ \\
\hline Agriculture & 0.5459 & 0.0650 & 0.5328 & 0.0794 \\
Extractive & $(0.0044)$ & $(0.0059)$ & $(0.0048)$ & $(0.0071)$ \\
& 0.5869 & 0.1374 & 0.5611 & 0.2205 \\
Manufacture & $(0.0159)$ & $(0.0188)$ & $(0.0154)$ & $(0.0189)$ \\
Energy & 0.6818 & 0.0664 & 0.6603 & 0.1122 \\
Construction & $(0.0019)$ & $(0.0017)$ & $(0.0024)$ & $(0.0029)$ \\
Sales & 0.5482 & 0.1125 & 0.5084 & 0.1455 \\
Transport & $(0.0105)$ & $(0.0155)$ & $(0.0116)$ & $(0.0155)$ \\
Tourism & 0.5893 & 0.1091 & 0.5775 & 0.1217 \\
& $(0.0017)$ & $(0.0014)$ & $(0.0011)$ & $(0.0014)$ \\
Education-Health & 0.6467 & 0.0781 & 0.6345 & 0.0994 \\
Other non-financial services & 0.6197 & 0.0829 & 0.6104 & 0.0986 \\
& $(0.0015)$ & $(0.0011)$ & $(0.0011)$ & $(0.0010)$ \\
\hline Observations & 0.6727 & 0.0967 & 0.6594 & 0.1147 \\
Notes: Bootstrap standard errors in parentheses & $(100$ replications). & & $(0.0011)$ \\
\hline \hline
\end{tabular}


Table A.2: Comparison of LP estimates for different definitions of capital (1995-2012).

\begin{tabular}{ccccccc}
\hline \hline & $\begin{array}{c}\text { Total capital } \\
\text { at book value }\end{array}$ & \multicolumn{2}{c}{$\begin{array}{c}\text { Tangible capital } \\
\text { at book value }\end{array}$} & \multicolumn{2}{c}{$\begin{array}{c}\text { Tangible capital } \\
\text { at market value }\end{array}$} \\
\cline { 2 - 7 } & $\beta_{L}$ & $\beta_{K}$ & $\beta_{L}$ & $\beta_{K}$ & $\beta_{L}$ & $\beta_{K}$ \\
\hline OLS & 0.6608 & 0.1125 & 0.6702 & 0.0934 & 0.6700 & 0.0997 \\
& $(0.0065)$ & $(0.0032)$ & $(0.0066)$ & $(0.0031)$ & $(0.0065)$ & $(0.0031)$ \\
FE & 0.7752 & 0.0931 & 0.7893 & 0.0636 & 0.7860 & 0.0740 \\
& $(0.0057)$ & $(0.0030)$ & $(0.0057)$ & $(0.0028)$ & $(0.0057)$ & $(0.0029)$ \\
LP & 0.5630 & 0.0787 & 0.5658 & 0.0731 & 0.5710 & 0.0778 \\
& $(0.0069)$ & $(0.0086)$ & $(0.0066)$ & $(0.0067)$ & $(0.0068)$ & $(0.0060)$ \\
\hline
\end{tabular}

Notes: Obs $=86,185$. Bootstrap standard errors in parentheses (100 replications).

Figure A.1: Changing composition of temporary workers.
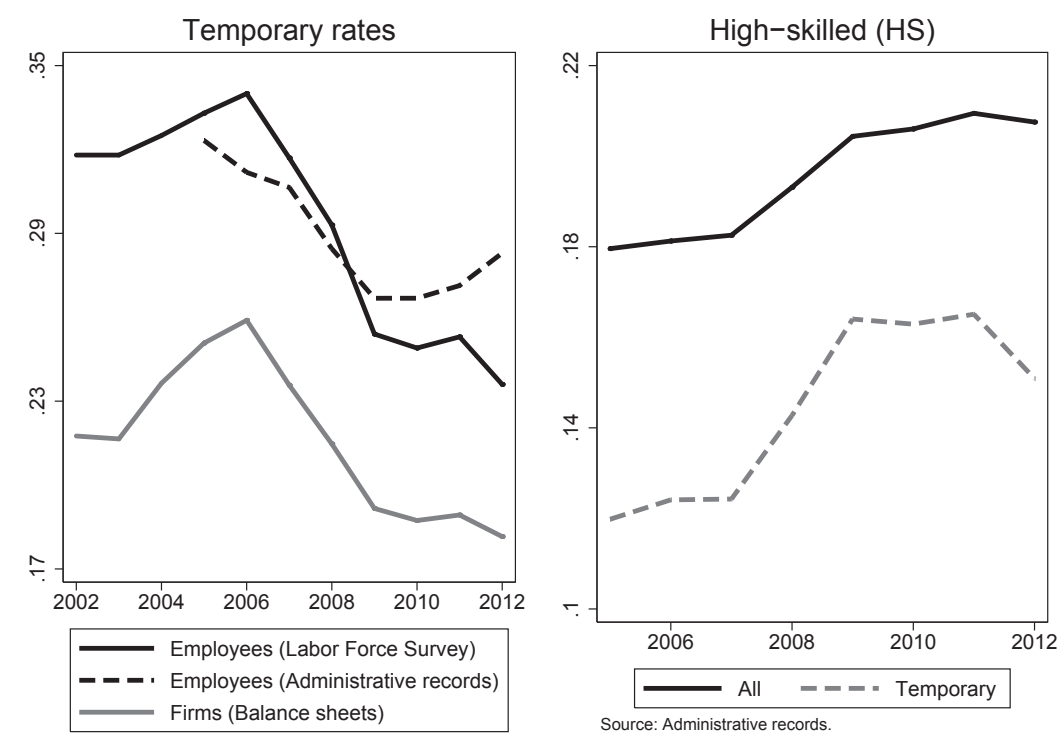
Table A.3: Firm fixed effects regression of estimated TFP growth.

\begin{tabular}{|c|c|c|c|c|}
\hline & $\begin{array}{c}\text { Full } \\
\text { sample }\end{array}$ & $\begin{array}{l}\text { Sample with } \\
\text { financial data }\end{array}$ & $\begin{array}{l}\text { Controlling for } \\
\text { financial data }\end{array}$ & $\begin{array}{l}\text { Tighter definition } \\
\text { importer/exporter }\end{array}$ \\
\hline Share of temporary workers & $\begin{array}{c}-0.0267^{* * *} \\
(0.0016)\end{array}$ & $\begin{array}{c}-0.0314^{* * *} \\
(0.0023)\end{array}$ & $\begin{array}{c}-0.0315^{* * *} \\
(0.0023)\end{array}$ & $\begin{array}{c}-0.0315^{* * *} \\
(0.0023)\end{array}$ \\
\hline Importer/exporter & $\begin{array}{c}0.0305^{* * *} \\
(0.0012)\end{array}$ & $\begin{array}{c}0.0189^{* * *} \\
(0.0016)\end{array}$ & $\begin{array}{c}0.0195^{* * *} \\
(0.0016)\end{array}$ & \\
\hline Importer/exporter (2008 threshold) & & & & $\begin{array}{c}0.0258^{* * *} \\
(0.0019)\end{array}$ \\
\hline Firm agreement & $\begin{array}{l}0.0215^{*} \\
(0.0128)\end{array}$ & $\begin{array}{l}-0.0050 \\
(0.0168)\end{array}$ & $\begin{array}{l}-0.0049 \\
(0.0169)\end{array}$ & $\begin{array}{l}-0.0050 \\
(0.0169)\end{array}$ \\
\hline Province agreement & $\begin{array}{c}-0.0039^{* *} \\
(0.0016)\end{array}$ & $\begin{array}{c}-8.85 \mathrm{e}-05 \\
(0.0022)\end{array}$ & $\begin{array}{c}-1.04 \mathrm{e}-05 \\
(0.0022)\end{array}$ & $\begin{array}{l}7.59 \mathrm{e}-06 \\
(0.0022)\end{array}$ \\
\hline Regional agreement & $\begin{array}{l}-0.0042 \\
(0.0029)\end{array}$ & $\begin{array}{l}-0.0015 \\
(0.0040)\end{array}$ & $\begin{array}{l}-0.0011 \\
(0.0040)\end{array}$ & $\begin{array}{l}-0.0010 \\
(0.0040)\end{array}$ \\
\hline National agreement & $\begin{array}{c}-0.0046^{* * *} \\
(0.0017)\end{array}$ & $\begin{array}{l}-0.0010 \\
(0.0023)\end{array}$ & $\begin{array}{l}-0.0008 \\
(0.0023)\end{array}$ & $\begin{array}{l}-0.0008 \\
(0.0023)\end{array}$ \\
\hline Debt ratio & & & $\begin{array}{c}-0.0108^{* * *} \\
(0.0006)\end{array}$ & $\begin{array}{c}-0.0108^{* * *} \\
(0.0006)\end{array}$ \\
\hline Short term ratio & & & $\begin{array}{c}0.0014^{* * *} \\
(0.0005)\end{array}$ & $\begin{array}{c}0.0014^{* * *} \\
(0.0005)\end{array}$ \\
\hline 10-19 employees & $\begin{array}{c}-0.0884^{* * *} \\
(0.0012)\end{array}$ & $\begin{array}{c}-0.0820^{* * *} \\
(0.0016)\end{array}$ & $\begin{array}{c}-0.0822^{* * *} \\
(0.0016)\end{array}$ & $\begin{array}{c}-0.0823^{* * *} \\
(0.0016)\end{array}$ \\
\hline 20-49 employees & $\begin{array}{c}-0.153^{* * *} \\
(0.0021)\end{array}$ & $\begin{array}{c}-0.142^{* * *} \\
(0.0026)\end{array}$ & $\begin{array}{c}-0.142^{* * *} \\
(0.0026)\end{array}$ & $\begin{array}{c}-0.142^{* * *} \\
(0.0026)\end{array}$ \\
\hline$>50$ employees & $\begin{array}{c}-0.246^{* * *} \\
(0.0053)\end{array}$ & $\begin{array}{c}-0.215^{* * *} \\
(0.0061)\end{array}$ & $\begin{array}{c}-0.215^{* * *} \\
(0.0061)\end{array}$ & $\begin{array}{c}-0.216^{* * *} \\
(0.0061)\end{array}$ \\
\hline Constant & $\begin{array}{c}0.570^{* * *} \\
(0.102)\end{array}$ & $\begin{array}{c}0.514^{* * *} \\
(0.159)\end{array}$ & $\begin{array}{c}0.515^{* * *} \\
(0.158)\end{array}$ & $\begin{array}{c}0.517^{* * *} \\
(0.158)\end{array}$ \\
\hline Observations & $4,655,781$ & $2,603,968$ & $2,603,968$ & $2,603,968$ \\
\hline
\end{tabular}


Figure A.2: Time variation in adjustment margins: TFP levels vs. TFP growth.
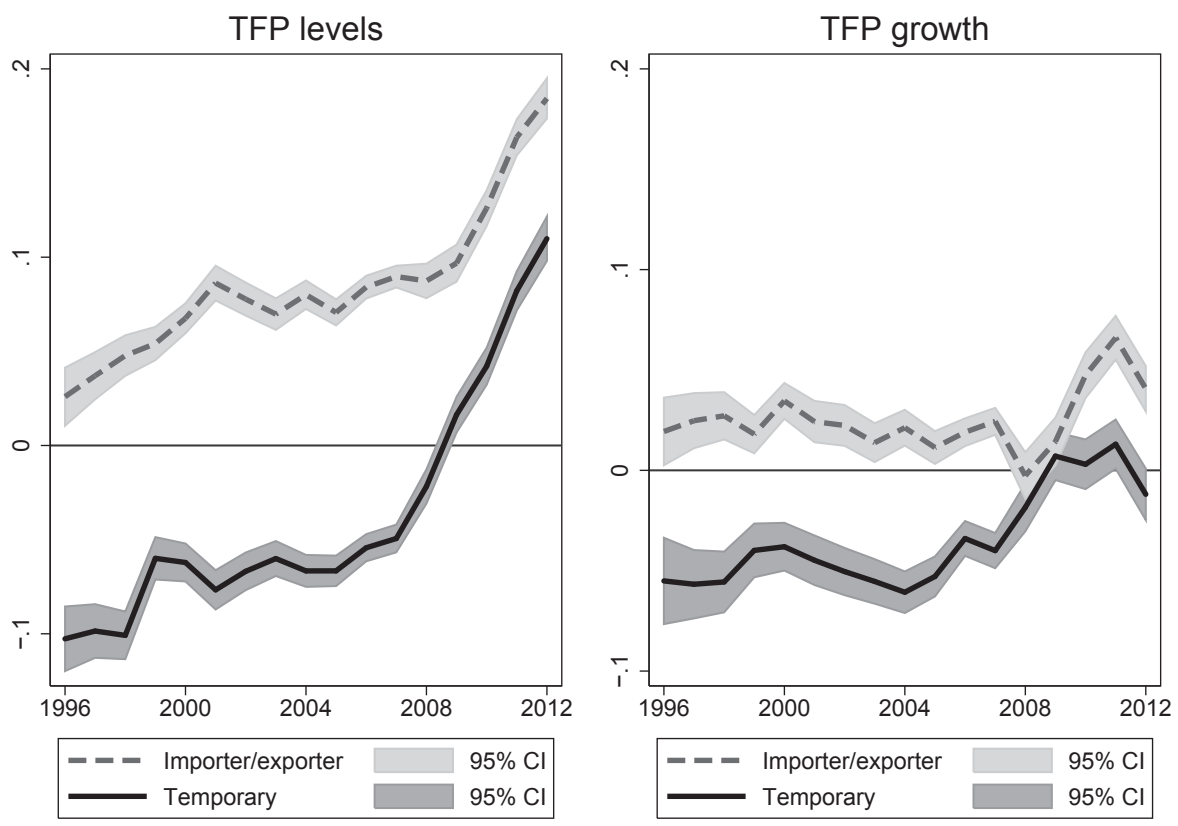

Notes: Estimates from firm fixed effect regressions of TFP on firm's age, size, region, sector, debt ratios, adjustment indicators, and interactions of these latter with time dummies. 